Jurnal Farmasi Galenika (Galenika Journal of Pharmacy) (e-Journal) 2020; 6 (1): 1 - 6 ISSN: 2442-8744 (electronic); 2442-7284 (printed) Journal Homepage: https://bestjournal.untad.ac.id/index.php/Galenika DOI: $10.22487 / j 24428744.2020 . v 6.11 .13928$

\title{
Analisis Profil Bobot Badan Tikus dan Gejala Toksis Pada Pemberian Ekstrak Etanol Daun Parang Romang (Boehmeria virgata) Terhadap Tikus Putih (Rattus novergicus)
}

\section{(Profile Analysis of Body Weight and Toxic Symptom of Rats in the Administration of Ethanol Extract of Parang Romang (Boehmeria virgata) Leaves to Male White Rats (Rattus novergicus))}

\author{
Magfirah $^{1 *}$, Vidya Christin $^{1}$

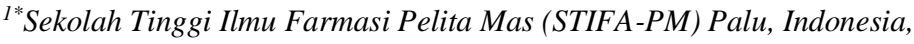 \\ E-mail: magfiralukman@gmail.com
}

Article Info:

Received: 10 Oktober 2019

in revised form: 10 Oktober 2019

Accepted: 23 Oktober 2019

Available Online: 23 Oktober 2019

\section{Keywords:}

Ethanol extract of Parang Romang

leaves

Profile of body weight

Toxic symptoms

Male white rat

Corresponding Author:

Magfirah

Sekolah Tinggi Ilmu Farmasi

Pelita Mas (STIFA-PM)

Palu

Indonesia

email: magfiralukman@gmail.com

\begin{abstract}
Traditional medicine is part of the Indonesian cultural heritage which has been used for generations and for centuries, but in general its safety has not been supported by adequate research. One of them is a parangromang which is empirically used by Makassar tribal healers as an antitumor. This study aims to determine the profile of body weight and toxic symptoms after 24 hours to 14 days including skin and fur changes, tremors and seizures, comaof rats in the administration of ethanol extract parang romang. White rats were divided randomly into 4 groups: group one was given $0.5 \%$ $\mathrm{NaCMC}$, groups of two, three and four were given extract at a dose of 175 $\mathrm{mg} / \mathrm{KgBB}$, $550 \mathrm{mg} / \mathrm{KgBB}$ and $1750 \mathrm{mg} / \mathrm{KgBB}$ for 14 days, the body weights of rats on days 0,7 and 14 days and toxic symptoms after 24 hours to 14 days. The results showed ethanol extract of parang romang leaves 550 $\mathrm{mg} / \mathrm{KgBB}$ had an effect on increasing body weight of rats and there were no changes in skin and fur, spasms, tremor, coma and death. It can be concluded that the ethanol extract of parang romang leaves has a significant effect on increasing the weight profile of male white rats and there are no toxic symptoms.
\end{abstract}

(c) (i) (2)

Copyright (C) 2019 JFG-UNTAD

This open access article is distributed under a Creative Commons Attribution (CC-BY-NC-SA) 4.0 International license.

How to cite (APA $6^{\text {th }}$ Style):

Magfirah, \& Christin, V. (2019). Analisis Profil Bobot Badan Tikus dan Gejala Toksis Pada Pemberian Ekstrak Etanol Daun Parang Romang (Boehmeria virgata) Terhadap Tikus Putih (Rattus novergicus). Jurnal Farmasi Galenika :Galenika Journal of Pharmacy (e-Journal), 6(1), 1-6. doi:10.22487/j24428744.2020.v6.i1.13928 


\section{ABSTRAK}

Obat tradisional merupakan bagian dari warisan budaya bangsa Indonesia yang telah digunakan secara turun temurun dan berabad-abad lamanya, namun secara umum keamanannya belum didukung oleh penelitian yang memadai. Salah satunya adalah tanaman parang romang (Boehmeriavirgata) yang secara empiris digunakan oleh pengobat suku makassar sebagai antitumor. Penelitian ini bertujuan untuk mengetahui profil bobot badan tikus dan gejala toksis pada pemberian ekstrak etanol daun parang romang. Tikus putih dibagi secara acak dalam 4 kelompok yaitu kelompok satu diberikan NaCMC 0,5\%, kelompok dua, tiga dan empat diberikan ekstrak dengan dosis masing-masing $175 \mathrm{mg} / \mathrm{KgBB}, 550 \mathrm{mg} / \mathrm{KgBB}$ dan $1750 \mathrm{mg} / \mathrm{KgBB}$ pengukuran bobot badan dilakukan pada hari ke 0,7 dan 14 hari dan gejala toksis berupa perubahan kulit dan bulu, kejang, temor, koma dan kematian diamati setelah 24 jam sampai 14 hari. Hasil penelitian menunjukkan dosis ekstrak etanol daun parang romang $550 \mathrm{mg} / \mathrm{KgBB}$ memberikan efek pada peningkatan bobot badan tikus dan tidak terdapat perubahan perubahan kulit dan bulu, kejang, tremor, koma dan kematian. Dapat disimpulkan bahwa ekstrak etanol daun parang romang memiliki pengaruh yang signifikan terhadap peningkatan profil bobot tikus putih jantan dan tidak terdapat gejala toksis.

Kata kunci: Ekstrak etanol daun parang romang, profil bobot badan, gejala toksis, tikus putih jantan.

\section{PENDAHULUAN}

Penggunaan obat tradisional untuk pencegahan dan pengobatan telah banyak digunakan terutama di negara-negara berkembang hingga mencapai $80 \%$ dan di negara maju penggunaan resep dengan pengobatan herbal juga akan terus meningkat (Ghadirkhomi et al., 2016). Namun karena berbagai hal seperti formulasi, cara pengolahan, penggunan dan kurangnya pemahaman terhadap efek yang timbulkan karena mengkonsumsi obat herbal, dapat mengakibatkan dampak yang buruk pada jaringan atau organ tubuh karena obat merupakan sasaran umum dari berbagai obat yang masuk ke dalam tubuh karena peran sentral dalam transportasi, metabolisme dan ekskresi bahan kimia asing di dalam tubuh (Gebremickael et al., 2017).

Parang romang atau Boehmeria virgata (Forst) Guil merupakan tumbuhan yang termasuk dalam suku Urticaceae yang digunakan secara empiris oleh pengobat suku Makassar Sulawesi Selatan sebagai obat antitumor (Manggau et al, 2011). Penelitian sebelumnya menyatakan bahwa ekstrak n-heksan memiliki aktivitas sitotoksikkuat terhadap sel line kanker servix HeLa secara in vitro dan tidak memiliki aktivitas sitotoksik terhadap sel normal sel vero (Wardihan et al. 2013).

Penelitian lain melaporkan bahwa ekstrak etanol parang romang beserta 3 tanaman obat masyarakat Makassar yang lain yaitu Acanthus ilicifolius Linn, Acalyphaindica L. dan Eupatorium odoratum telah diteliti aktivitasnya terhadap sel HeLa dan dilaporkan bahwa Boehmeria virgata memiliki aktivitas tertinggi dengan nilai IC50 berturut-turut yaitu 9,40; 32,81; 179,02 dan 223,64 $\mu \mathrm{g} / \mathrm{ml}$ (Lukman, M. et al. 2014). Sitotoksisitas selektif ekstrak etanol daun Boehmeria virgata terhadap beberapa cell lines kanker yaitu HeLa, Widr, T47D dan Vero cell lines serta berturut-turut nilai IC50 yang dihasilkan yaitu $8,991 \pm 0.234 ; 18,925 \pm 1,277 ; 12,732 \pm 0,945$ dan $16,022 \pm 0,663 \mu \mathrm{g} / \mathrm{ml}$ pen dengan masing-masing selektif indeks (SI) yaitu sebesar 0,844; 0,847; 1,258 dan 1,000 (Wardihan, et al 2013).

Penggunaan obat herbal daun parang romang secara empiris oleh masyarakat namun batas keamanannya belum didukung oleh peneltian. Tujuan penelitian ini dilakukan yaitu untuk mengetahui profil bobot badan tikus dan gejala toksis pada pemberian ekstrak etanol daun parang romang. Melalui penelitian ini diharapkan diperolehnya informasi pengaruh pemberian ekstrak etanol daun parang romang terhadap profil berat badan tikus dan gejala toksis. Dengan demikian, ekstrak etanol daun parang romang diharapkan dapat menjembatani pengembangan obat tradisional ke arah pemanfaatan dalam pelayanan kesehatan formal. 


\section{METODE PENELITIAN}

\section{Bahan}

Ekstrak etanol daun parang romang, tikus putih, pakan standar, $\mathrm{Na} \mathrm{CMC}$ dan aquadest.

\section{Pemilihan Dan Penanganan Hewan Uji}

Tikus putih jantan berumur 2 bulan dengan berat 150-200 g, digunakan pada studi ini dipelihara pada suhu kamar. Tikus diberikan pakan standar dan minum air secukupnya. Untuk setiap perlakuan, tikus yang digunakan adalah 5 ekor setiap perlakuan. Prosedur pengujian pada penelitian ini dilaporkan ke Komisi Etik Universitas Hasanuddin untuk mendapatkan persetujuan.

\section{Pembuatan Ekstrak Daun Parang Romang}

Sebanyak $800 \mathrm{~g}$ serbuk daun tumbuhan parang romang (Boehmeria virgata) dimaserasi dengan etanol sebanyak $4 \mathrm{~L}$ selama $3 \times 24$ jam, kemudian campuran sampel dan pelarut ini disaring hingga diperoleh ekstrak dan ampas, ampas yang dihasilkan kemudian kembali dimaserasi dengan pelarut yang sama. Langkah tersebut diulangi sampai 4 kali total maserasi, selanjutnya seluruh ekstrak yang diperoleh disatukan dan dipekatkan dengan Rotary Vacum Evaporator sampai diperoleh ekstrak etanol pekat.

\section{Pembuatan Larutan Uji Ekstrak Etanol Daun Parang Romang}

Pembuatan larutan ekstrak etanol daun parang romang dibuat dengan menimbang $437 \mathrm{mg}, 1375 \mathrm{mg}$, dan $1750 \mathrm{mg}$ masing-masing untk dosis berurut-turut $175 \mathrm{mg} / \mathrm{KgBB}, 550 \mathrm{mg} / \mathrm{KgBB}$ dan 1750 $\mathrm{mg} / \mathrm{KgBB}$ disuspensikan masing-masing ke dalam larutan $25 \mathrm{ml} \mathrm{Na} \mathrm{CMC}$.

\section{Penimbangan Berat Badan Tikus}

Semua hewan uji tikus ditimbang sebanyak 3 kali, hari ke 0 sebelum pemberian ekstrak, kemudian hari ke 7 dan hari ke 14 setelah pemberian ekstrak etanol daun parang romang.

\section{Analisis Gejala Toksis}

Analisis gejala toksis akut dilakukan dengan metode up down procedur (OECD, 425) dengan uji main test. Tikus terlebih dahulu dipuasakan selama 16 jam sebelum pemberian ekstrak etanol daun parang romang. Setelah dipuasakan, tikus diberikan dosis tunggal ekstrak etanol daun parang romang mulai dari dosis $175 \mathrm{mg} / \mathrm{KgBB}$ dan tikus diberikan makanan setelah 1-2 jam pemberian ekstrak etanol daun parang romang. Kemudian dilakukan pengamatan interval pada tikus setelah 48 jam bila tikus dapat bertahan, maka dosis ditingkatkan sebesar 3,2 kali dosis awal namun jika tikus mati maka dosis pemberian diturunkan. Bila interval setelah 48 jam tidak terjadi kematian pada hewan uji, maka dilanjutkan pada dosis berikutnya yaitu $550 \mathrm{mg} / \mathrm{KgBB}$ dan selanjutnya $1750 \mathrm{mg} / \mathrm{KgBB}$ dengan dosis tunggal. Pengamatan dilakukan dengan mengamati gejala berupa perubahan kulit dan bulu, kejang, temor, koma dan kematian diamati setelah 24 jam sampai 14 hari.

\section{Analisis Statistik}

Data dilaporkan sebagai mean \pm standard error mean (SEM). Analisis data dilakukan dengan analisis varians satu arah (ANOVA) diikuti dengan uji Tukey post-hoc dengan menggunakan software SPSS versi 23.0. Skor $\mathrm{P}<0,05$ dianggap signifikan secara statistik.

\section{HASIL DAN PEMBAHASAN}

Hasil penelitian pemberian ekstrak etanol pemberian berat badan dapat dilihat pada tabel 1 di bawah ini : 
Tabel 1. Hasil Pengukuran Profil Berat Badan Tikus

\begin{tabular}{|c|c|c|c|}
\hline \multirow{2}{*}{ Kelompok Perlakuan } & \multicolumn{3}{|c|}{ Berat Badan Tikus pada hari Ke } \\
\hline & 1 & 7 & 14 \\
\hline $\begin{array}{l}\text { Kontrol } \\
(1 \mathrm{ml} / 100 \mathrm{gNaCMC} 1 \%)\end{array}$ & $184,8 \pm 9.36$ & $187,6 \pm 10,50$ & $197.4 \pm 9.31$ \\
\hline Dosis $1(175 \mathrm{mg} / \mathrm{KgBB})$ & $184,6 \pm 9,31$ & $188,8 \pm 10,61$ & $201,6 \pm 10,78$ \\
\hline $\begin{array}{l}\text { Dosis } 2 \\
(550 \mathrm{mg} / \mathrm{KgBB})\end{array}$ & $184,4 \pm 9.28$ & $190,4 \pm 9,39$ & $212 \pm 11,03$ \\
\hline $\begin{array}{l}\text { Dosis } 3 \\
(1750 \mathrm{mg} / \mathrm{KgBB})\end{array}$ & $184,6 \pm 9,15$ & $192,4 \pm 9,20$ & $203 \pm 9,35$ \\
\hline
\end{tabular}

Hasil penelitian analisis gejala toksis ekstrak etanol daun parang romang dapat dilihat pada tabel 2 di bawah ini :

Tabel 2. Analisis Gejala Toksis

\begin{tabular}{|c|c|c|c|c|}
\hline Pengamatan & Dosis $(\mathrm{mg} / \mathrm{Kg} / \mathrm{BB}$ & 24 jam & 7 hari & 14 hari \\
\hline \multirow{3}{*}{ Kulit dan bulu } & 175 & $\mathrm{~N}$ & $\mathrm{~N}$ & $\mathrm{~N}$ \\
\hline & 550 & $\mathrm{~N}$ & $\mathrm{~N}$ & $\mathrm{~N}$ \\
\hline & 1750 & $\mathrm{~N}$ & $\mathrm{~N}$ & $\mathrm{~N}$ \\
\hline \multirow{3}{*}{ Kejang } & 175 & - & - & - \\
\hline & 550 & - & - & - \\
\hline & 1750 & - & - & - \\
\hline \multirow[t]{3}{*}{ Tremor } & 175 & - & - & - \\
\hline & 550 & - & - & - \\
\hline & 1750 & - & - & - \\
\hline \multirow[t]{3}{*}{ Koma } & 175 & - & - & - \\
\hline & 550 & - & - & - \\
\hline & 1750 & - & - & - \\
\hline \multirow[t]{3}{*}{ Kematian } & 175 & - & - & - \\
\hline & 550 & - & - & - \\
\hline & 1750 & - & - & - \\
\hline
\end{tabular}

Tanaman parang romang, khususnya bagian daun secara empiris digunakan sebagai antitumor oleh pengobat suku Makassar. Akan tetapi batas keamanan penggunaan daun parang romang belum diteliti lebih lanjut oleh karena itu penelitian ini bertujuan untuk mengetahui pengaruh ekstrak etanol daun parang romang secara oral terhadap bobot badan tikus dan analisis gejala toksis pada pemakaian berbagai variasi dosis ekstrak etanol daun parang romang terhadap tikus putih. Pada penelitian ini, daun parang romang diekstraksi dengan menggunakan metode maserasi. Dari metode maserasi diperoleh rendemen sebesar $6.25 \%$ (50 gram dari 800 gram serbuk daun parang romang). Metode maserasi dipilih karena merupakan metode ekstraksi yang paling sederhana dan dapat digunakan untuk mengekstraksi bahan-bahan yang tidak tahan terhadap pemanasan (Sa'adah \& Nurhasnawati, 2015).

Penimbangan bobot badan hewan uji dilakukan setiap minggu sebanyak 3 kali yaitu hari ke 0 sebelum pemberian ekstrak, kemudian hari ke 7 dan hari ke 14 setelah pemberian ekstrak. Berdasarkan pada tabel 1, penimbangan berat badan tikus pada kelompok perlakuan kontrol, dosis 1, dosis 2 dan dosis 3 pada tikus diperoleh nilai rata-rata bobot badan tikus mengalami peningkatan berat badan, terlihat dimana setiap minggu berat badan tikus meningkat. Pada dosis 2 tikus mengalami peningkatan berat 
badan yang lebih besar. Perubahan berat badan secara nyata merupakan indikator yang paling mudah terlihat dan menjadi indikator awal adanya efek toksik dari sampel uji yang diberikan. Bobot badan pada studi toksisitas, hewan coba yang mendapat dosis tinggi umumnya kehilangan berat badan yang disebabkan penurunan nafsu makan. (Sireeratawong et al.,2010). Dimana jumlah intake pakan tikus/ ekor setiap hari adalah $10 \%$ dari bobot badan tikus. Hasil uji statistik Analisis varian satu arah (One Way Anova $)$ diperoleh nilai $\mathrm{p}=0.001 \quad(\mathrm{p}<0,05)$ menunjukkan peningkatan berat badan secara signifikan pada setiap kelompok perlakuan dibandingkan kelompok normal. Dimana dosis $550 \mathrm{mg} / \mathrm{Kg}$ BB menunjukkan efek yang dapat meningkatkan bobot badan tikus.

Selain bobot badan tikus, analisis gejala toksis dilakukan dengan metode OECD 425 dengan uji main test. Pengamatan dilakukan dengan mengamati gejala berupa perubahan kulit dan bulu, kejang, tremor, koma dan kematian diamati setelah 24 jam pemberian ekstrak etanol daun parang romang sampai 14 hari. Pada tabel 2, pengamatan gejala toksis dilakukan selama 14 hari pada semua kelompok perlakuan. Pengamatan gejala toksis meliputi ada/tidaknya perubahan pada kulit dan bulu, kejang, tremor, koma dan kematian pada tikus setelah pemberian ekstrak etanol daun parang romang. Hasil pengamatan gejala toksis ekstrak etanol daun parang romang secara oral pada tikus putih jantan tidak memperlihatkan gejala toksis berupa perubahan pada kulit dan bulu, kejang, tremor, koma dan tidak adanya kematian pada tikus dari berbagai kelompok perlakuan dan kelompok kontrol. Tujuan dilakukan pengamatan ini yaitu untuk mengetahui ada tidaknya efek toksis dari ekstrak etanol daun parang romang yang diberikan secara oral selama 14 hari.

\section{KESIMPULAN}

Dari hasil penelitian dan pembahasan dapat disimpulkan bahwa pemberian ekstrak etanol daun parang romang (Boehmeria virgata) dengan 3 variasi dosis secara oral selama 14 hari meningkatkan berat badan tikus pada setiap kelompok perlakuan dan tidak adanya gejala toksis pada setiap kelompok perlakuan. Dosis yng paling efektif dalam meningkatkan berat badan tikus adalah dosis $550 \mathrm{mg} / \mathrm{Kg}$ BB.

\section{DAFTAR PUSTAKA}

Gebremickael, A., Gebru, G., Debella, A., \& Addis, G. (2017) Acute and Sub-chronic Oral Toxicity Evaluation Of Eucalyptus globulus Essential Oil-water Emulsion in Rats. Journal of Cytology \& Histology, 8(2), 1-5.

Ghadirkhomi, A., Safaeian, L., Zolfaghari, B., Ghazvini, A. R. M., \& Rezaei, P. (2016). Evaluation of acute and sub-acute toxicity of Pinuseldarica bark extract in Wistar rats. Avicenna J Phytomed, 6(5), 558-566.

Lukman, M., Rusdi, M., Hatta, M., Rahman, L., Subehan, \& Manggau, M. (2014). Anti proliferation activity of Nanoencapsulated bioadhesive vaginal gel of isolated active Compound (BVI03) from Boehmeriavirgata (Forst) guill leaves against human cancer cervix Hela cells. International Journal of Pharma Sciences and Research, 6, 836-839.

Manggau, M., Hasan, H., Wahyudin, E., Haryono, K., Mufidah, \& Lukman (2011). Efek Farmakologi Tanaman Antikanker yang Digunakan oleh Masyarakat Sulawesi Selatan, Balitbangda Sulawesi Selatan. ISBN 9786028400558.

OECD. (2008). Oecd Guideline For Testing Of Chemicals Acute Oral Toxicity - Up-and-DownProcedure (UDP) Class Method. OECD Enviroment Directorate, Environment, Health and Safety Division.

Sa'adah, H., \& Nurhasnawati, H. (2015). Perbandingan Pelarut Etanol dan Air Pada Pembuatan Umbi Bawang Tiwai (Eluetherine americana Merr.) Menggunakan Metode Maserasi. Jurnal Ilmiah Manuntung, 1(2), 149-153. 
Sireeratawong, S., Piyabhan, P., Singhalak, T., Wongkrajang, Y., Temsiririrkkul, R., Punsrirat, J. (2010). Toxicity evaluation of sappan wood extract in rats. J Med Assoc Thail, 93(7), S50-S57.

Wardihan, Rusdi, M., Alam, G., Lukman, \& Manggau, M. (2013). Selective Cytotoxicity Evaluation in Anticancer Drug Screening of Boehmeriavirgata (Forst) Guill Leaves to Several Human Cell Lines: HeLa, WiDr, T47D and Vero. Dhaka Univ. J. Pharm. Sci, 12(2), 87-90. 